Article

\title{
Greenhouse Gas Emissions of Stationary Battery Installations in Two Renewable Energy Projects
}

\author{
Johanna Pucker-Singer ${ }^{1}$, Christian Aichberger ${ }^{1, * \mathbb{C}}$, Jernej Zupančič ${ }^{2}$, Camilla Neumann ${ }^{1}$, David Neil Bird ${ }^{1} \mathbb{D}$, \\ Gerfried Jungmeier ${ }^{1}$, Andrej Gubina ${ }^{2}{ }^{\mathbb{D}}$ and Andreas Tuerk ${ }^{1}$ \\ 1 Joanneum Research Forschungsgesellschaft mbH, LIFE-Institute for Climate, Energy and Society, \\ Waagner-Biro Straße 100, 8020 Graz, Austria; johanna.pucker-singer@joanneum.at (J.P.-S.); \\ camilla.neumann@joanneum.at (C.N.); neil.bird@joanneum.at (D.N.B.); \\ gerfried.jungmeier@joanneum.at (G.J.); andreas.tuerk@joanneum.at (A.T.) \\ 2 Laboratory of Energy Policy, Faculty of Electrical Engineering, Univerza v Ljubljani, Tržaška Cesta 25, \\ SI-1000 Ljubljana, Slovenia; jernej.zupancic@fe.uni-lj.si (J.Z.); andrej.gubina@fe.uni-lj.si (A.G.) \\ * Correspondence: LIFEOffice@joanneum.at; Tel.: +43-316-876-7600
}

Citation: Pucker-Singer, J.; Aichberger, C.; Zupančič, J.; Neumann, C.; Bird, D.N.; Jungmeier, G.; Gubina, A.; Tuerk, A. Greenhouse Gas Emissions of Stationary Battery Installations in Two Renewable Energy Projects. Sustainability 2021, 13, 6330. https://doi.org/10.3390/ su13116330

\section{Academic Editors:}

Morteza Nazari-Heris, Gevork

B. Gharehpetian,

Behnam Mohammadi-Ivatloo and Somayeh Asadi

\section{Received: 30 April 2021}

Accepted: 1 June 2021

Published: 3 June 2021

Publisher's Note: MDPI stays neutral with regard to jurisdictional claims in published maps and institutional affiliations.

Copyright: (c) 2021 by the authors. Licensee MDPI, Basel, Switzerland. This article is an open access article distributed under the terms and conditions of the Creative Commons Attribution (CC BY) license (https:// creativecommons.org/licenses/by/ $4.0 /)$.

\begin{abstract}
The goal to decrease greenhouse gas (GHG) emissions is spurring interest in renewable energy systems from time-varying sources (e.g., photovoltaics, wind) and these can require batteries to help load balancing. However, the batteries themselves add additional GHG emissions to the electricity system in all its life cycle phases. This article begins by investigating the GHG emissions for the manufacturing of two stationary lithium-ion batteries, comparing production in Europe, US and China. Next, we analyze how the installation and operation of these batteries change the GHG emissions of the electricity supply in two pilot sites. Life cycle assessment is used for GHG emissions calculation. The regional comparison on GHG emissions of battery manufacturing shows that primary aluminum, cathode paste and battery cell production are the principal components of the GHG emissions of battery manufacturing. Regional variations are linked mainly to high grid electricity demand and regional changes in the electricity mixes, resulting in base values of $77 \mathrm{~kg}$ $\mathrm{CO}_{2}$-eq/ $\mathrm{kWh}$ to $153 \mathrm{~kg} \mathrm{CO}$-eq/kWh battery capacity. The assessment of two pilot sites shows that the implementation of batteries can lead to GHG emission savings of up to $77 \%$, if their operation enables an increase in renewable energy sources in the electricity system.
\end{abstract}

Keywords: energy storage; batteries; renewable energy; life cycle assessment

\section{Introduction}

The importance of energy storages in an electricity system with a high share of renewable energy sources is well known. In general, energy storages offer the possibility to balance the fluctuating electricity production from distributed renewable sources (DRES), like wind power [1] and photovoltaic plants [2], with the electricity demand in grid-scale applications [3]. DRES heavily implemented in distribution networks can cause voltage rises, current congestion and even reverse power flows in the network, while on other side massive implementation of heat pumps and electric vehicles represent increased electricity demand that can lead to overloading of network and undervoltage. The distribution network operators face new challenges to provide their users with stable and secure operation of the grid and providing their services within the power quality boundaries. Energy management systems provide solutions for controlling flexible devices and mitigation of their impact on the network. In addition to control systems [4], implementation of storage technologies in the system further improves the network conditions and mitigates the impact of DRES in charging the storage and impact of increased load in discharging from the unit [5]. In this article, we focus on batteries being one energy storage technology that is used to reduce the influence of DRES on the network and mitigate demand peaks in industrial and residential environments. 
On one hand, the use of batteries in distribution networks is driven by the increased demand for renewable sources to decrease the greenhouse gas (GHG) emissions of the electricity supply. On the other hand, the battery system itself adds an additional environmental impact to the electricity system as a new system component, which needs to be produced, operated and finally disposed and/or recycled. Consequently, GHG emissions are added to the system in all these life-cycle phases.

A recent review on the life cycle assessment (LCA) of stationary batteries in grid applications highlighted that while the production of Li-ion batteries is examined in a growing amount of reports, the use phase of stationary lithium-ion (Li-ion) batteries is not assessed sufficiently [6]. Moreover, several assessments also conclude that in most cases the use phase and not the manufacturing dominates life cycle impacts [6]. Hiremath et al. [7] and Baumann et al. [8] both emphasize that the round-trip efficiency of the batteries and the electricity mix of the system in which the battery is integrated are important factors influencing the GHG emissions of the use phase. For batteries used for frequency regulation, Ryan et al. came to the same results, while the implementation of batteries can also affect the electricity mix of the investigated grid [9]. However, Vandepaer et al. [10] found that battery production causes most GHG emissions. They investigated Li-ion battery production in Asia, which has a high reliance on coal-based electricity for the production process. For the use phase, they assumed electricity production from wind power, which explains the low GHG emissions for this phase of the battery life cycle. These differing results highlight the importance of considering all life cycle phases when investigating GHG emissions of battery systems.

In this study, we address two research questions: (1) What are the GHG emissions of the manufacturing of two stationary batteries, installed and operated in two pilot sites in Europe, considering different battery production locations? (2) How are the GHG emissions of the electricity supply of these two pilot sites changed by the battery integration?

The assessment is based on real-world applications. The first pilot site is located in Suha, Slovenia, where a medium scale battery $(170 \mathrm{~kW}, 552 \mathrm{kWh})$ was connected to a $400-\mathrm{kVA}$ OLTC medium/low voltage (MV/LV) transformer station of DSO Elektro Gorenjska supplying the Suha village residential grid. The second pilot site is located in Navarra, Spain, where a Li-ion battery was installed in a factory in addition to an existing PV plan. The battery has a charging and discharging power of $50 \mathrm{~kW}$ and a capacity of $222 \mathrm{kWh}$.

Besides environmental impacts, technical and economic factors are also important for the implementation of energy storage technologies. In [11], the authors assess all three dimensions for the Slovenian and Spanish pilot sites, among others. In this paper, we focus on the GHG emissions of the pilot sites in detail and add information on the GHG emissions of battery manufacturing.

\section{Materials and Methods}

To assess the GHG emissions of battery manufacturing and the pilot sites, we used the method of "Life Cycle Assessment (LCA)". According to ISO 14040 [12], LCA addresses the environmental aspects and potential environmental impacts (e.g., use of resources and the environmental consequences of releases) throughout a product's life cycle from raw material acquisition through production, use, end-of-life treatment, recycling and final disposal.

Global Warming Potential on a 100-year time horizon (GWP 100) was used to express the contribution of the GHG emissions (e.g., $\mathrm{CH}_{4}, \mathrm{~N}_{2} \mathrm{O}, \mathrm{CFC}$, HCFCs, Organ chloride, HFCs) to global warming, in terms of equivalent amount of $\mathrm{CO}_{2}\left(\mathrm{CO}_{2}\right.$-eq). $\mathrm{CO}_{2}$-eq factors were taken from [13] using the factors including climate carbon feedback. $\mathrm{CO}_{2}$ emissions from burning biomass were balanced zero according to IPCC guidelines [14].

\subsection{GHG Emission Calculation of Battery Manufacturing}

The GHG emission calculation of battery manufacturing includes the mining, refining and processing of materials up to battery grade, the production of battery cells and the 
assembly of the battery pack by adding a battery management system, cooling system and casings. On the basis of a recent literature review on environmental life cycle impacts of automotive batteries [15], the calculation of GHG emissions from battery manufacturing was done with our in-house "JR Battery LCA Tool" [16]. As the chemistry of various Li-ion batteries used in automotive and stationary applications are similar, material inventories were adapted and expanded by adding additional electronic equipment like inverters and steel containers, based on data from Ecoinvent 3.4 [17].

Background data was mainly gathered from the databases GREET 2019 [18], Ecoinvent 3.4 [17] and GEMIS 5.0 [19]. For regional variation of the manufacturing process, we included national electricity mixes from the International Energy Agency (IEA), mainly based on available data for the year 2018 [20]. We varied the region of manufacturing for those materials, which were found to influence total GHG emissions of battery production by more than $1 \%$ when their specific emission factor of $\mathrm{x} \mathrm{kgCO}_{2} / \mathrm{kg}$ material, stated in GREET 2019, is varied by $20 \%$. Additionally, we varied the electricity mix and the share of energy sources used in battery cell production.

A battery consists of cells (cathode, anode, electrolyte, separator, cell case) that are bundled into modules. The modules are then connected and assembled with the addition of a battery management system, cooling system and a casing. These components are made from various materials. In the case of Li-ion batteries, the main materials are lithium, nickel, cobalt, aluminum, copper, graphite and steel.

In an LCA perspective, used energy sources for production processes are highly relevant, especially when those processes are energy intensive. However, energy sources can vary depending on the production location and national electricity mixes. Therefore, a comparison of batteries produced in China, the United States and Europe was done to show how environmental impacts of the battery systems can be affected by the production location. Currently, most batteries are produced in Asia and the US [21]. Table 1 shows an overview of the battery systems installed in Suha, Slovenia; and Navarra, Spain. As the base case, the battery system in Suha is produced in China, while the battery system in Navarra is manufactured in the US. The two cathode paste chemistries NMC (Lithium Nickel Manganese Cobalt Oxide) and NCA (Lithium Nickel Cobalt Aluminum Oxide) are also common for the application in electric vehicles [15]. In stationary battery applications, additional further electronic equipment like power conversion systems (PCS), energy management systems (EMS) and master control units have to be considered together with the production of containers for housing the whole equipment.

Table 1. Data on the battery systems.

\begin{tabular}{ccc}
\hline Category & Suha, Slovenia & Navarra, Spain \\
\hline Cathode paste & NMC 111 & NCA \\
Charging/discharging power $[\mathrm{kW}]$ & 170 & 50 \\
Installed capacity [kWh] & 552 & 222 \\
Used capacity [kWh] & 320 & 222 \\
Weight of battery system [kg] & 4136 & 2174 \\
Gravimetric energy density on cell level & 198 & 149 \\
[Wh/ $/ \mathrm{kg}]$ & 0.88 & 0.97 \\
Roundtrip efficiency & 4 (constant load) & - \\
Auxiliary power ${ }^{[}[\mathrm{kW}]$ & 10 & Indoor \\
Lifetime [a] & Outdoor & 1559 (2 containers) \\
Installation site & Additional equipment & Galvanized Sheet Steel Louvers \\
\hline Container [kg] & 2319 & Microgrid Manager: 185 \\
Container material & Stainless Steel & Control Unit: 1
\end{tabular}

\footnotetext{
${ }^{1}$ for heating and cooling of the container due to outdoor installation.
} 
As our functional unit, we chose $1 \mathrm{kWh}$ of battery capacity as this enables a useful comparison between batteries with different gravimetric energy densities. Note that the environmental impact assessment of the battery in Suha is related to the used capacity of $320 \mathrm{kWh}$ instead of $552 \mathrm{kWh}$, as the battery was intentionally over dimensioned for project purposes and only the needed capacity is assessed. Evaluation of the GHG emissions was done in two steps by assessing the battery racks separately and adding emissions from additional electronic equipment and the containers afterwards. The material shares by weight for the battery systems in Suha and Navarra without additional equipment can be seen in Figure 1. They are similar.

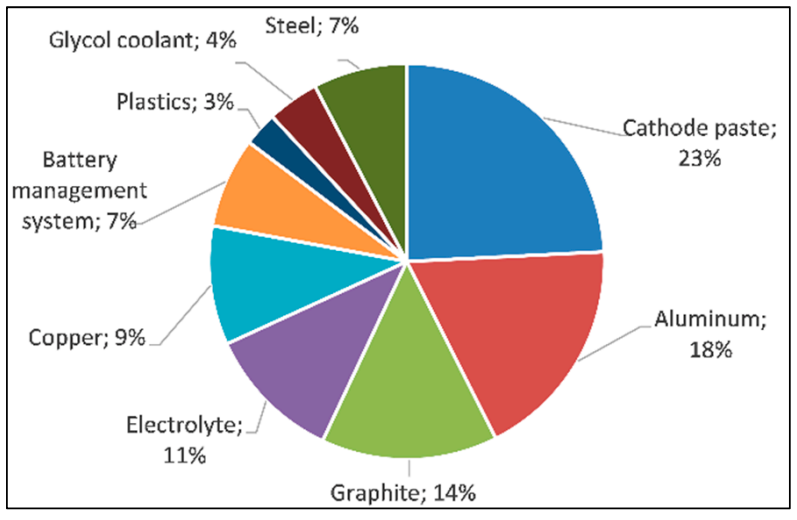

(a)

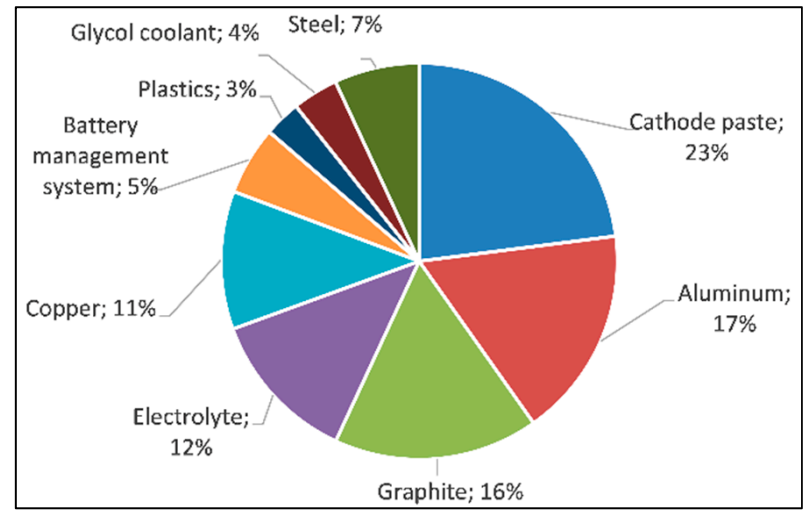

(b)

Figure 1. Material shares by weight for the battery systems in (a) Suha; (b) Navarra.

\subsection{GHG Emission Calculation of a Battery Storage in a Low Voltage Substation in Suha, Slovenia}

The goal of the LCA for the Suha pilot site was to estimate the GHG emissions of the medium scale battery connected to a MV/LV transformer station supplying a residential grid. Therefore, we compared use cases (UC) with and without batteries, to assess contribution of the battery on the GHG emissions of the electricity supply to Suha village.

Figure 2 shows the basic layout of the investigated system. Local PV plants and electricity from the grid cover the electricity demand of the households. Surplus electricity is injected into the power grid and/or stored in the battery.

The LCA was performed for two UC, which differ in the included components and the way PV electricity is handled:

- UC1: PV curtailment application: the limitations from the distribution grid are considered. If demanded by the PV droop control, the PV production is curtailed due to increased voltage levels in the network.

- UC2: BESS implementation: the battery system placed at the MV/LV transformer station is considered. The battery performs peak shaving. It charges in intervals with high PV production and discharges during the morning and evening demand peaks. In addition, the battery charges during the night, only up to $100 \mathrm{~kW}$ of power flows in the network, and the battery is not allowed to lower power flows in the network below $50 \mathrm{~kW}$ during the day. PV production is curtailed with droop control if needed.

The GHG emissions of both UC were investigated for two different amounts of PV units installed in the grid: $210 \mathrm{kWp}$ (low PV scenario) and $630 \mathrm{kWp}$ (high PV scenario) installed peak power (Table 2). The low PV scenario represents the amount of installed PV power in the year 2017 in the investigated grid section. The high PV scenario is a fictitious scenario that represents a future situation with more PV plants. 


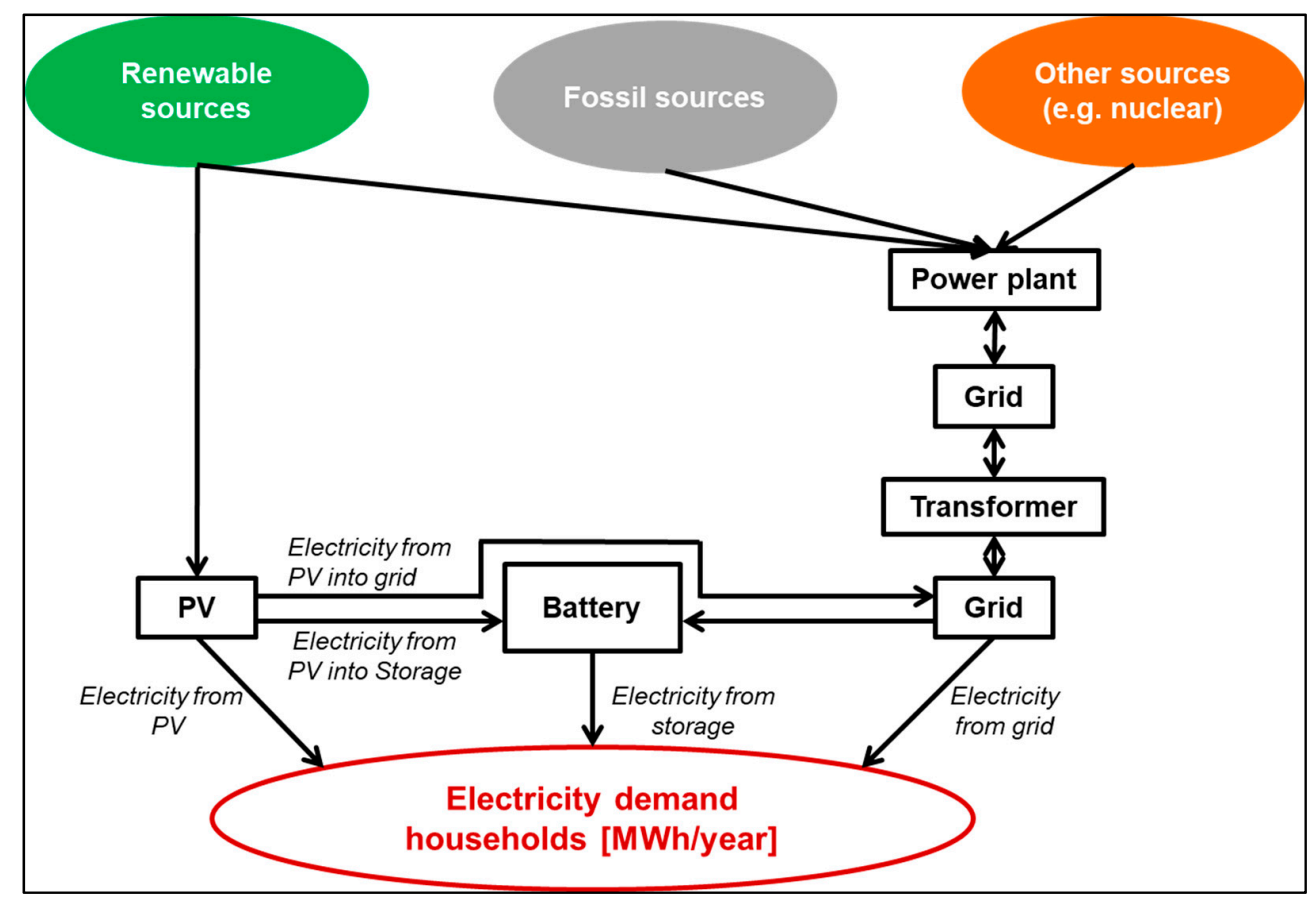

Figure 2. A simplified scheme of the Slovenian pilot site displaying energy flows and system components most relevant for the LCA.

Table 2. Data on the PV scenarios.

\begin{tabular}{ccccc}
\hline Scenarios & PV Units & $\begin{array}{c}\text { PV Peak Power } \\
{[\mathbf{k W}]}\end{array}$ & $\begin{array}{c}\text { PV Area } \\
{\left[\mathbf{m}^{2}\right]}\end{array}$ & $\begin{array}{c}\text { Life Time }^{2} \\
{[\mathbf{a}]}\end{array}$ \\
\hline Low RES & 6 & 210 & 1591 & 30 \\
High RES & 18 & 630 & 3773 & 30 \\
\hline
\end{tabular}

${ }^{1}$ Calculated using a nominal conversion efficiency of $13.2 \%$ for multi-crystalline silicone module [22]. ${ }^{2}$ Assumption according to [22].

If the PV electricity can neither be consumed in the residential grid nor stored in the battery, then it is injected into the MV grid. This energy affects the electricity generation in the network: thus, electricity generation by other power plants can be replaced. To include the effect from surplus PV generation on the electricity generation mix of the system, we investigated four options for the consumed and replaced grid electricity in order to represent different power system preconditions:

- Option 1: For the consumed and replaced grid electricity, the Slovenian electricity mix is used.

- Option 2: For the consumed grid electricity, the Slovenian electricity mix is used. For surplus PV electricity, it is assumed that the electricity generation in a natural gas power plant is replaced, since natural gas power plants, as flexible electricity generation units, are high on the merit order curve of the day-ahead electricity market.

- Option 3: For surplus PV electricity, it is assumed that this electricity is stored in a pumped storage power plant connected at the HV grid level. For the consumed grid electricity, the Slovenian electricity mix plus the share of electricity stored in the pumped storage power plant—reduced by storage and transmission losses, is used.

- Option 4: For the consumed and replaced grid, electricity generation with a natural gas power plant is assumed.

Two types of data were used in the LCA calculation: (1) foreground data and (2) background data. Foreground data were specifically collected for the pilot site. Background data were taken from life cycle databases $[17,23]$ and are summarized in Table A1. 
Demonstration-specific data was used on the installed battery system (Table 1) and if possible, monitoring data from the demonstration were used as foreground data (e.g., battery efficiency, auxiliary energy demand of the battery system, electricity demand of households, electricity generation from PV) and implemented in a technical grid simulation or directly used in the LCA calculation. Simulation platform, designed in MATLAB [24] and OpenDSS [25] software environment, provided results for additional network configuration. With simulations, both UC1 and UC2 were investigated for low and high PV scenario as an extension of the data, obtained from demonstration. The impact of PV control and storage implementation can be observed through results, which include power flows in the LV grid, energy losses, voltage profiles and loading levels of the network elements. The technical grid simulation also delivered the annual energy flows of the UCs for the LCA calculation, which are presented in Table 3.

Table 3. Annual energy balance of the investigated UCs of the Suha pilot site.

\begin{tabular}{|c|c|c|c|c|c|c|}
\hline & Demand & PV Generation & PV to MV Grid & PV Consumed & $\begin{array}{c}\text { Electricity } \\
\text { from MV Grid }\end{array}$ & Total Losses \\
\hline & \multicolumn{6}{|c|}{ [MWh/a] } \\
\hline \multicolumn{7}{|c|}{210 kWp PV installed-low PV scenario } \\
\hline UC1: PV curtailment & 458 & 191 & 136 & 56 & 412 & 10 \\
\hline $\begin{array}{c}\text { UC2: BESS } \\
\text { implementation }\end{array}$ & 458 & 194 & 81 & 113 & 367 & 22 \\
\hline \multicolumn{7}{|c|}{$630 \mathrm{kWp}$ PV installed-high PV scenario } \\
\hline UC1: PV curtailment & 458 & 444 & 349 & 95 & 377 & 14 \\
\hline $\begin{array}{c}\text { UC2: BESS } \\
\text { implementation }\end{array}$ & 458 & 555 & 388 & 167 & 325 & 34 \\
\hline
\end{tabular}

In the different UCs, consumption of grid electricity and replacement of grid electricity occur at different times during the day. Depending on the electricity generation technologies, the generation mix changes over the year and during daytime. Therefore, the calculation of GHG emissions of consumed and replaced grid electricity was performed using hourly GHG emission factors. Historic data on the hourly Slovenian electricity generation mix was taken from [26] for the period between January 2017 and January 2018. Based on these sources we calculated an annual average GHG emission factor for the Slovenian mix, which is $365 \mathrm{~kg} \mathrm{CO}_{2}$-eq/MWh electricity.

\subsection{GHG Emission Calculation of a Battery Storage in a Factory in Navarra, Spain}

The goal of this LCA was to investigate the impact of a $50 \mathrm{~kW} \mathrm{Li-ion} \mathrm{battery} \mathrm{in}$ combination with an existing PV plant on the GHG emissions of the electricity supply of a factory.

Figure 3 shows in a simplified scheme the main processes, which were included in the LCA calculation. The electricity demand of the factory is covered by the PV plant and from the MV grid.

To assess the role of the battery and the PV plant again different UC were defined:

- UC0: no PV, no battery: In this use case, the electricity demand of the factory is covered by electricity from the MV grid only. It is a reference case showing the situation without the existing PV panels and battery.

- UC1: PV: As shown in Figure 3, the electricity demand of the factory is partly covered by PV panels installed on the buildings of the factory. Surplus electricity from the PV panels is injected into the MV grid. The remaining electricity demand from the factory is covered from the MV grid. This UC is the currently valid legal situation in Spain, which became active in 2015 as RD 900/2015 came into force.

- UC2: PV + battery (no charging from grid): Here, the electricity demand of the factory is partly covered by PV panels. Surplus electricity from the PV panels is stored in a battery and used at peak times and at times with high grid electricity costs. If the 
battery is fully charged, surplus PV electricity is injected into the grid. The remaining electricity demand is covered from the MV grid. In this UC, the battery is only charged with PV electricity. Charging of the battery with grid electricity is not possible. This reflects the situation at the demonstration site during the first operation phase of the battery.

- UC3: PV + battery (charging from grid): UC3 is very similar to UC2. The only difference is that in UC3 it is possible to charge the battery with grid electricity. It reflects the situation at the demonstration during the second operation phase of the battery, after a change in legislation.

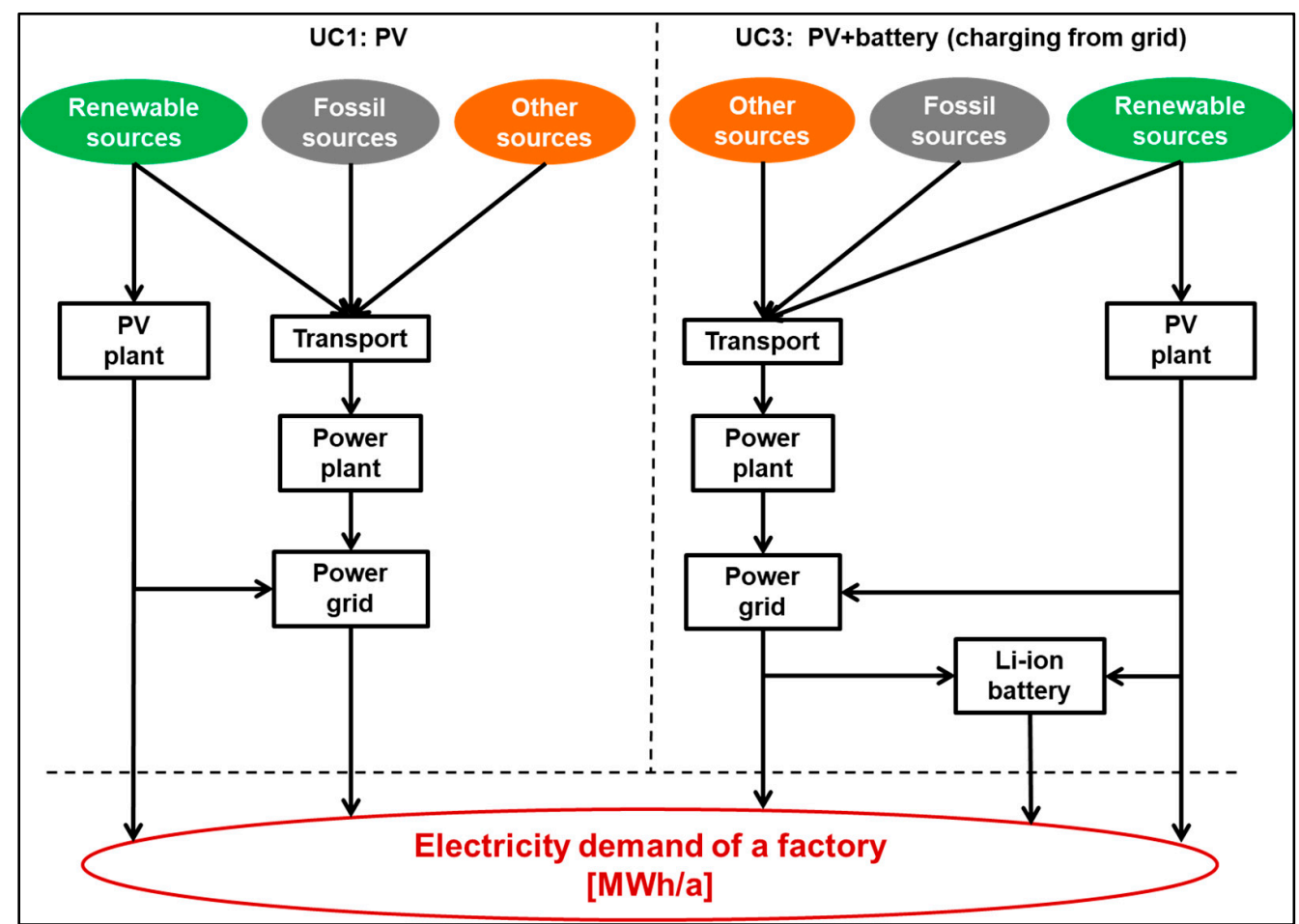

Figure 3. A simplified scheme of the Spanish pilot site displaying energy flows and system components most relevant for the LCA.

In the case UC2 and UC3, surplus electricity from the PV plant is stored in the battery. In "UC3: PV + battery (charging from grid)" the battery is also charged with grid electricity at low-tariff times. If the PV electricity can neither be consumed in the factory nor stored in the battery, then it is injected into the MV grid. For this situation, we investigated the same four options for consumed and replaced grid electricity as described in Section 2.2. The only difference is that for this demonstration site we used the Spanish electricity mix. Again, we used hourly GHG emission factors to account for changes in the electricity generation mix over the year and during the daytime. Historic data on the hourly Spanish electricity generation mix was taken from [26] for the period between January 2019 and January 2020. Based on these data, different emission factors per use case were calculated. However, the differences in the results per use case were very small. The average GHG emissions factor for the calculated Spanish grid electricity mix was 206 or $207 \mathrm{~g} \mathrm{CO}_{2}$-eq/kWh in all use cases.

Data on the battery (Table 1) and PV system (Table 4) as well as monitoring data from their operation were collected as input data for the LCA. These data were implemented in a technical model to calculate the annual energy balance for the four different UCs (Table 5). 
Table 4. Data on the PV scenarios.

\begin{tabular}{cccc}
\hline & $\begin{array}{c}\text { PV Peak Power } \\
{[\mathbf{k W} \text { ] }]}\end{array}$ & $\begin{array}{c}\text { PV Area } \\
{\left[\mathbf{~}^{2}{ }^{2}\right.}\end{array}$ & $\begin{array}{c}\text { Life Time }^{2} \\
{[\mathbf{a}]}\end{array}$ \\
\hline PV unit & 112.7 & 854 & 30 \\
\hline $\begin{array}{l}{ }^{1} \text { Calculated using a nominal conversion efficiency of } 13.2 \% \text { for multi-crystalline silicone module }[22] .{ }^{2} \text { Assump- } \\
\text { tion according to [22]. }\end{array}$
\end{tabular}

Table 5. Annual energy balance of the investigated UCs of the Spanish pilot site.

\begin{tabular}{|c|c|c|c|c|c|c|}
\hline & Demand & PV Generation & PV to Grid & PV Consumed & $\begin{array}{l}\text { Electricity } \\
\text { from Grid }\end{array}$ & Total Losses \\
\hline & \multicolumn{6}{|c|}{ [MWh/a] } \\
\hline UC0: no PV, no battery & 485 & 0 & 0 & 0 & 485 & 0 \\
\hline UC1: PV & 485 & 171 & 32 & 139 & 346 & 0 \\
\hline $\begin{array}{c}\text { UC2: PV + battery } \\
\text { (no charging from grid) }\end{array}$ & 485 & 171 & 22 & 149 & 342 & 6 \\
\hline $\begin{array}{l}\text { UC3: PV + battery } \\
\text { (charging from grid) }\end{array}$ & 485 & 171 & 22 & 149 & 341 & 5 \\
\hline
\end{tabular}

\section{Results and Discussion}

The result section is divided into three parts. In the first subsection, we present and discuss the results on the GHG emissions of the manufacturing of the two batteries that were installed at the two demonstration sites. Here, we include the influence of producing the batteries in three different regions. In the second and third parts, we focus on the implementation of these batteries at the two pilot sites in Suha, Slovenia; and Navarra, Spain. We present the change in GHG emissions for these pilot sites due to the battery integration, adding a wider system perspective. We take into account all elements needed to cover the electricity demand at the pilot sites: electricity production from PV plants, electricity consumption and injection into a higher grid level, and the battery.

\subsection{GHG Emissions of Battery Manufacturing-A Regional Comparison}

\subsubsection{Accounting for Uncertainty}

The modeling of the calculation, data sensitivities due to limited primary data for rapidly evolving battery production processes and a recent literature review of battery LCA studies [15] showed that the regional energy mix for covering the energy demand of production processes is a major factor for differences in GHG emissions. However, factors like different energy consumption values in specific processes can also influence the GHG emissions. Therefore, the numerical results in the following figures of the regional comparison of battery manufacturing are presented as ranges to account for possible data variations between current specific processes and production plants.

\subsubsection{GHG Emissions of Battery Materials Production}

A range of 60 to $70 \mathrm{~kg} \mathrm{CO}$-eq/kWh battery capacity was stated by Romare and Dahllöf [27] as the most likely value for battery-grade material production based on the assessment of transparency and scientific method in literature sources. Looking at the GHG emissions of materials mining, refining and processing up to battery grade, the region of production is especially important for materials with high electricity demands in the production process. To account for further data variations in energy consumption, etc., for the investigated regional material production processes, we adopted an uncertainty range of $\pm 5 \mathrm{~kg} \mathrm{CO}$-eq/ $\mathrm{kWh}$ battery capacity for the total emissions of the production of materials and allocate this uncertainty to the single values.

Visible in Figures 4 and 5, primary aluminum is the key driver for regional GHG emission differences due to its electricity intensive production process. National differences 
in electricity supply are therefore highly relevant and the process-specific electricity mixes in primary aluminum smelting enhance this factor. In Europe and the US, the electricity for aluminum smelting is mainly generated by hydro power, whereas Chinese aluminum manufacturers use electricity mostly from coal power plants [28]. The integration of aluminum in the cathode, cooling system and especially in casings is the most relevant difference for regional impacts of battery materials for both battery systems. This was also emphasized by Kelly et al. [29]. We assume a share of around $10 \%$ secondary aluminum used for the battery racks in line with estimations from Dai et al. [30], as a too high share may not meet material requirements for battery application. The applied regional electricity mix is also relevant for the production of the cathode paste, based on the production process described by Dai et al. [30], and the battery management system (BMS).

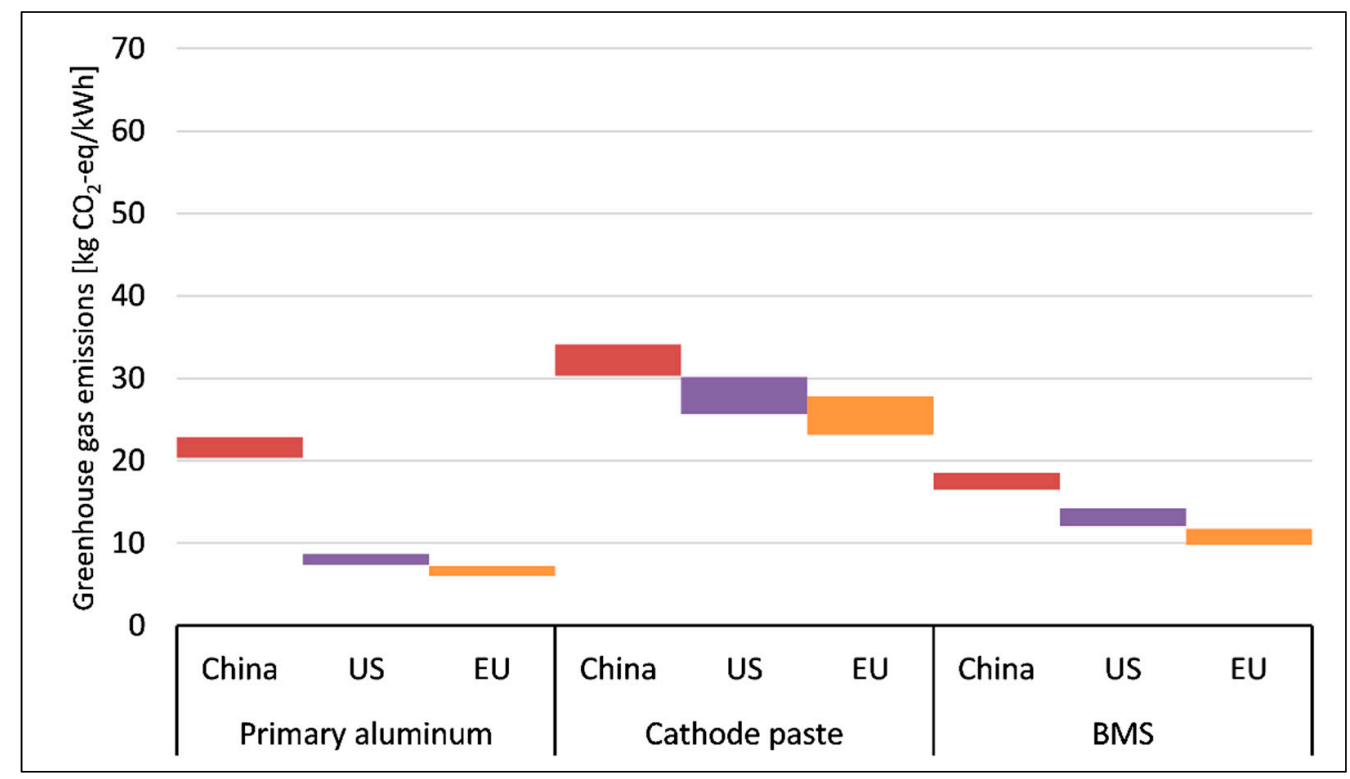

Figure 4. Regional GHG emissions variation for relevant materials of the battery in Suha.

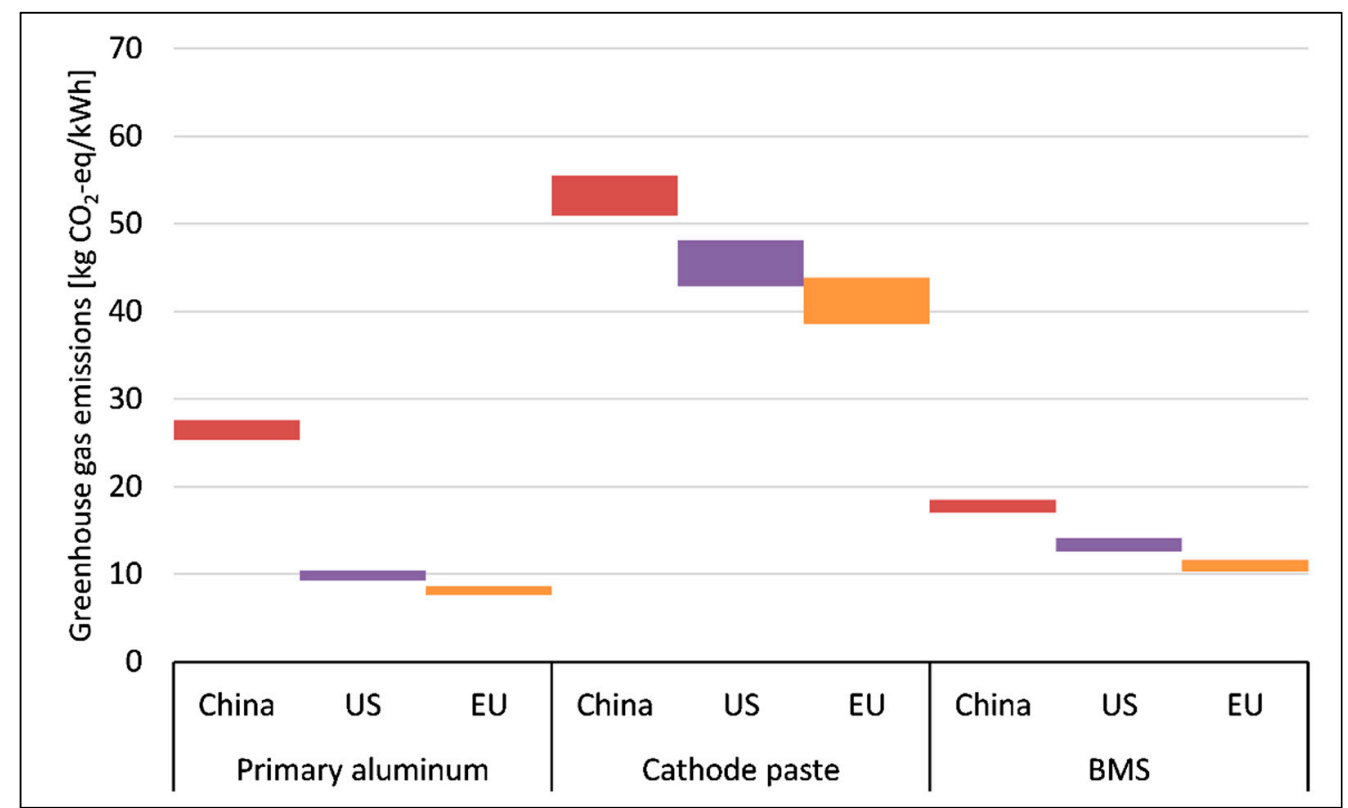

Figure 5. Regional GHG emissions variation for relevant materials of the battery in Navarra.

In addition, to provide $1 \mathrm{kWh}$ of storage capacity, a lower gravimetric energy density of the battery data in Navarra leads to a higher material demand and therefore increased GHG 
emissions as compared to the battery in Suha. The difference between Navarra and Suha is dominated by the high material shares and specific GHG emissions of aluminum and the cathode paste in the battery. In line with other literature [15], the material composition of the cathode pastes (NMC in Suha versus NCA in Navarra) is not a significant influence on GHG emissions.

\subsubsection{GHG Emissions of Battery Cell/Pack Production}

The main cause for strongly differing results on GHG emissions of Li-ion battery production is the limited availability of primary data on the energy demand of the battery cell production process [15]. Data on the energy demand from small underutilized pilot-scale factories (e.g., around $163 \mathrm{kWh} / \mathrm{kWh}$ battery capacity) [31] included process inefficiencies and is therefore not applicable for industrial-scale production facilities [30]. The dry room with its constant energy demand for providing the right climatic conditions is a major factor for inefficiencies in such facilities and therefore the throughput of the factory should be as high as possible for an efficient production process [30]. We assume a mean value of $60 \mathrm{kWh} / \mathrm{kWh}$ battery capacity based on Davidsson Kurland [32]. Adapting the data of Emilsson and Dahllöf [33] and Davidsson Kurland [32], we distribute 20-25 kWh to the dry room, 18-21 kWh to electrode drying and up to $15 \mathrm{kWh}$ to cell formation (initial charging and discharging). To account for uncertainty due to varying specific energy consumption values of battery cell manufacturing in different production plants, we adopt the range of 50 to $65 \mathrm{kWh} / \mathrm{kWh}$ battery capacity from Davidsson Kurland [32].

In general, electricity and heat are needed to cover the energy demand, which is covered either by solely electricity or by fossil fuels like natural gas. The regional electricity mix and a possible integration of renewable electricity sources, which could supply the process completely, can vary results highly [32]. Ellingsen et al. [31] based their data on a pilot scale facility that covered its energy demand solely by electricity, while Dai et al. [30] investigated a Chinese industrial scale manufacturing process that used natural gas to supply $80 \%$ of the needed energy. Current data from the Swedish manufacturer Northvolt supports the assumption of Davidsson Kurland that Dai et al. underestimated the electricity consumption of cell formation [32]. Adjusting the values, we assume for the base case that heat from natural gas makes up 50\% of the energy demand and electricity from the national grid covers the other half. A sensitivity analysis in Figure 6 also depicts the GHG emissions of an energy supply based on $100 \%$ electricity from the national electricity grid or from photovoltaics.

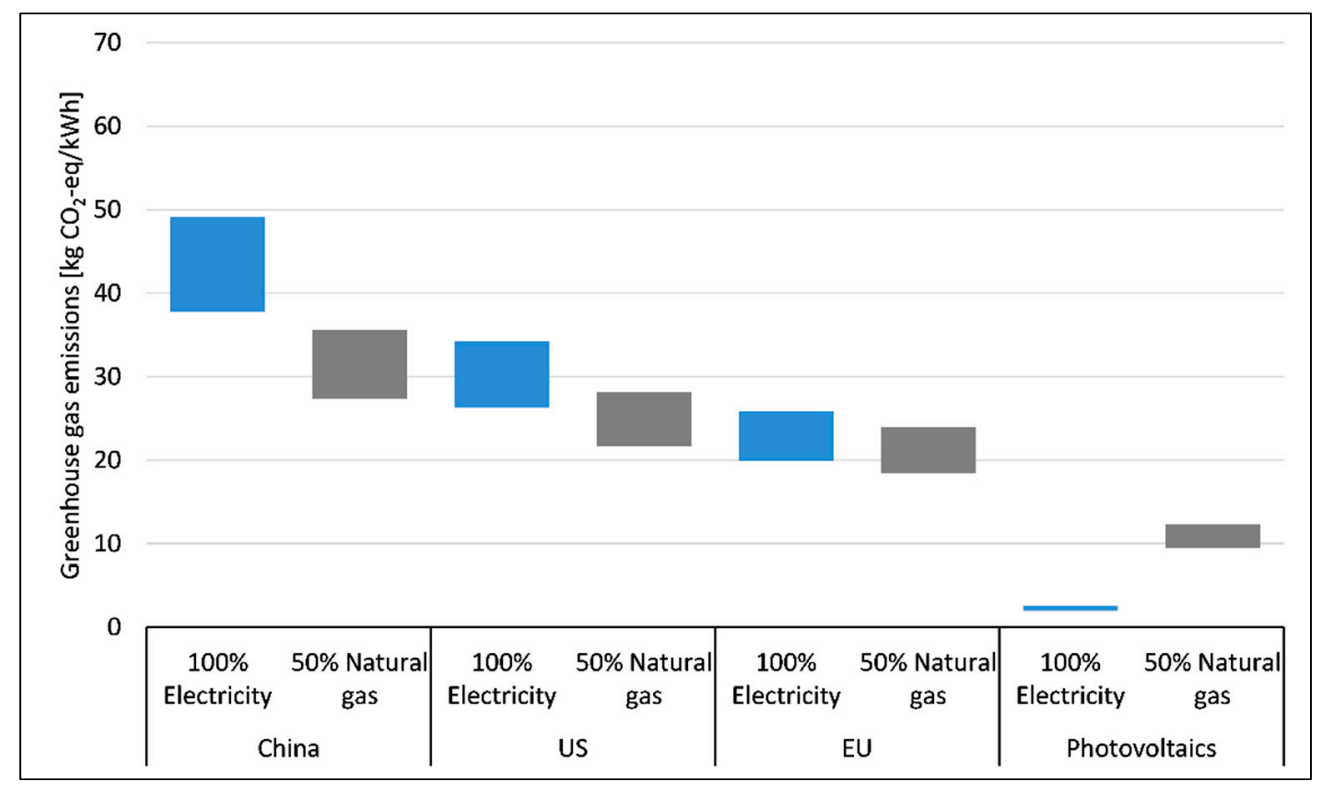

Figure 6. Sensitivity analysis of GHG emissions from cell production. 
Looking at Figure 6, GHG emissions of a production process relying solely on electricity are highly sensitive to the electricity mix and a strong difference is visible between the coal intensive Chinese grid and the other regions. Carbon-intensive coal power supplies around two-thirds of the Chinese electricity demand while coal covers only around one-third of the demand in the US and Europe [20]. As energy from natural gas is less carbon-intensive than coal, it is at least a short-term option for GHG emissions reduction. However, electricity from photovoltaics has the lowest GHG emission intensity.

Compared to the impacts of material emissions, the cell production process has lower GHG emissions. We neglected the further production process of the battery pack, as the adding of a battery management system, cooling system and casing is done by manual labor with negligible environmental impact [30,31]. Figures 7 and 8 depict the GHG emissions of the total battery production process. In addition to GHG emissions of battery materials and battery production, the transportation from the battery production location to Suha and Navarra, respectively, is included, which shows only minor GHG emissions. As discussed earlier, per $\mathrm{kWh}$ storage capacity, material production for the battery in Navarra shows higher GHG emissions due to a lower gravimetric energy density and therefore a higher demand for materials compared to the battery in Suha.

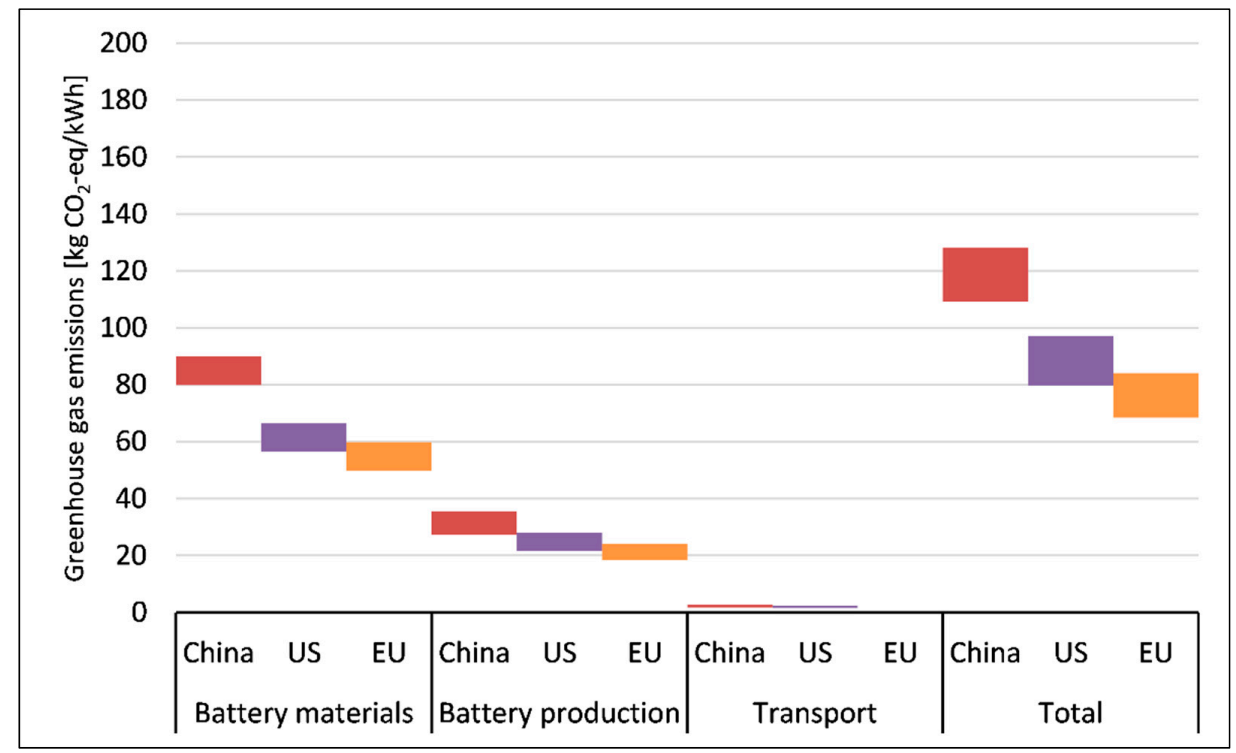

Figure 7. GHG emissions for the battery modules in Suha.

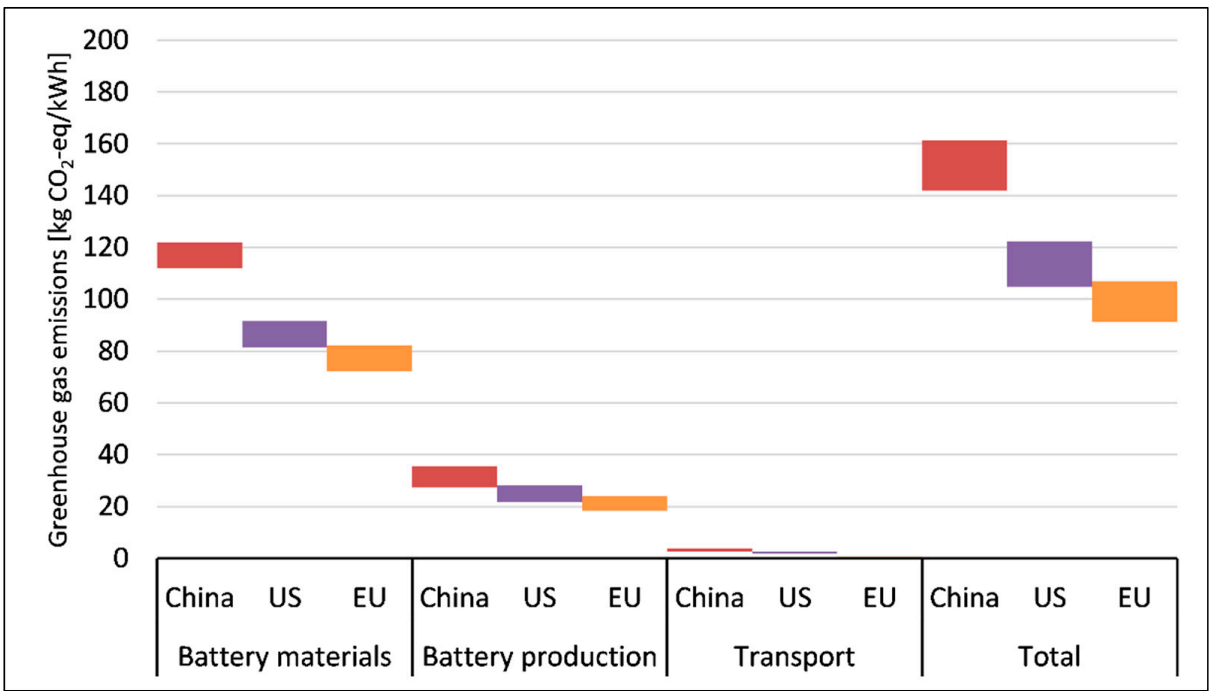

Figure 8. Results for the battery modules in Navarra. 
3.1.4. Total GHG Emissions including Emissions from Electronic Equipment and Containers

We did not vary the production location for additional electronic equipment and the steel container housing and took global values from Ecoinvent 3.4 [17] for production of these components and added an uncertainty range of $\pm 5 \mathrm{~kg} \mathrm{CO}_{2}$-eq/ $\mathrm{kWh}$ battery capacity. Visible in Figure 9, the results for additional equipment per kWh battery capacity are very similar between the battery system in Suha and Navarra. In addition, the battery systems themselves show similar results, as we assume for the base case a production in China for the battery in Suha and a production in the US for the battery in Navarra.

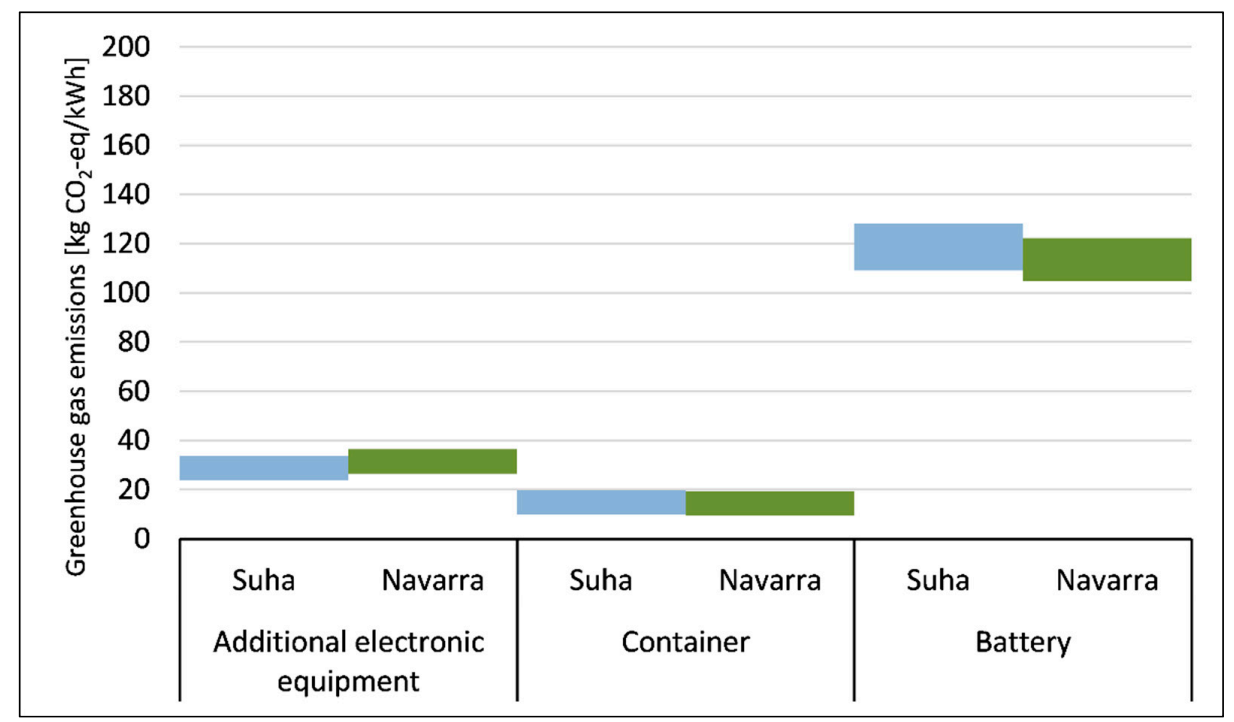

Figure 9. GHG emissions from additional equipment and the battery, assuming production for the Suha battery in China and the Navarra battery in the US.

In Appendix A, Tables A2 and A3 show our GHG emissions results for the regional comparison.

\subsection{GHG Emissions of a Battery Storage in a Low Voltage Substation in Suha, Slovenia}

For the electricity supply in the Suha residential grid, we calculated the annual GHG emissions for two PV scenarios with $210 \mathrm{~kW}$ PV and $630 \mathrm{~kW} \mathrm{PV.} \mathrm{Figure} 10$ depicts the results for the investigated UCs and the contributions from PV plant manufacturing, battery manufacturing, electricity consumed from grid and electricity supplied to the grid. If the $\mathrm{PV}$ generation level covers all demand in the grid and the surplus energy can neither be consumed nor stored, it is injected into the MV grid. This energy flow affects the electricity generation in the network and electricity generation by other power plants is replaced. Therefore, the GHG emissions for electricity supplied to the grid are negative. In Figure 10, the Slovenian electricity mix was used for consumed and replaced grid electricity.

In the scenario with $210 \mathrm{kWp}$ PV power, the "UC2: BESS implementation" has slightly higher GHG emissions (123 t $\mathrm{CO}_{2}$-eq/year) than the "UC1: PV curtailment" (114 t CO ${ }_{2}^{-}$ eq/year). The advantage of less GHG emissions for grid electricity consumption does not compensate for the lower amount of saved GHG emissions and the additional GHG emissions for battery manufacturing. With an installed PV power of $210 \mathrm{kWp}$, curtailment of the PV plants is practically not needed, as the grid is able to handle almost the full amount of generated PV electricity. The generated PV electricity is consumed within the Suha residential grid or it is transported to the next grid level and consumed within the electricity system by other customers. However, in "UC2: BESS implementation" electricity losses due to storage losses in the battery and auxiliary energy demand of the battery occur, which adds GHG emissions for consumed grid electricity and reduces negative GHG emissions for injected grid electricity. 


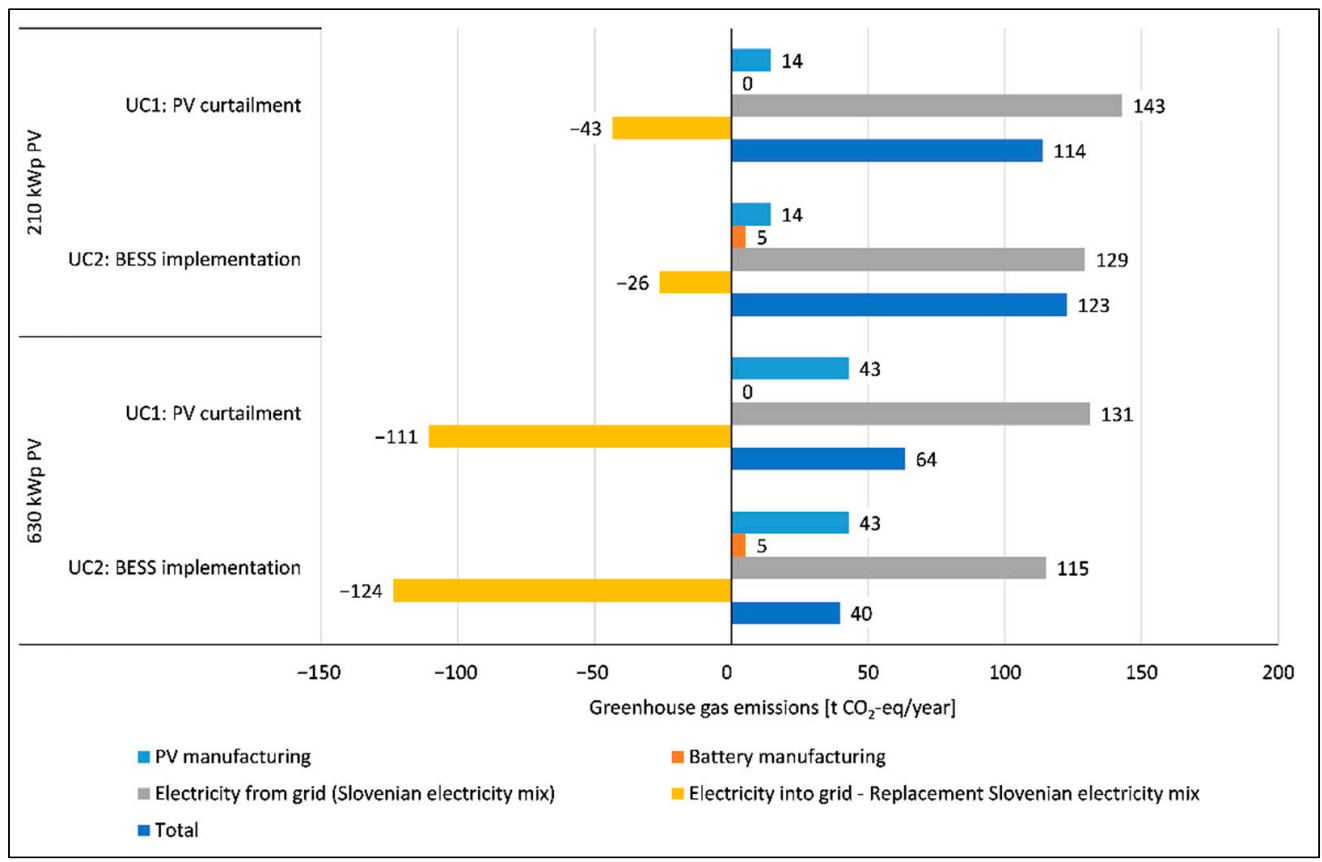

Figure 10. Annual GHG emissions for the Slovenian pilot site (Slovenian grid mix for consumed and replaced grid electricity).

The situation changes in the second scenario, where $630 \mathrm{kWp}$ PV are installed. Here, the grid model showed grid limitations and, in both use cases, curtailment is needed. However, in use case "UC2: BESS implementation" less curtailment is needed using the battery for peak shaving. Therefore, GHG emissions for consumed grid electricity are lower in use case "UC2: BESS implementation", but also, saved GHG emissions are higher as the amount of PV electricity injected into the next grid level is higher.

Our results including the manufacturing and use phase of the battery are in line with the conclusions from Pellow et al. [6], Hiremath et al. [7], Baumann et al. [8] and Ryan et al. [9], that in most cases the use phase and not the manufacturing dominates life cycle impacts. For the Suha pilot site, the GHG emissions of the manufacturing of the complete battery system are estimated to be $52 \mathrm{t} \mathrm{CO}_{2}$-eq, considering an Asian production location. Assuming a lifetime of 10 years, the yearly GHG emissions for the battery manufacturing are approximately $5 \mathrm{t} \mathrm{CO}_{2}$-eq. This represents $4 \%$ of the total annual GHG emission in UC1 and 13\% in UC2, with a higher share of renewable electricity. In the use phase, the battery itself does not emit GHG emissions. However, the battery operation influences the amount of consumed and replaced grid electricity by factors such as roundtrip efficiency of the battery, auxiliary energy demand for cooling and heating of the battery container and the operation strategy of the battery. Figure 10 shows that the change in GHG emissions for consumed and replaced grid electricity in UC2, linked to battery operation, is higher compared to GHG emissions for battery manufacturing. GHG emissions for consumed grid electricity are changed by $-14 \mathrm{t} \mathrm{CO}_{2}$-eq in the $210 \mathrm{kWp}$ PV scenario and in the $630 \mathrm{kWp}$ PV scenario by $-16 \mathrm{t} \mathrm{CO}_{2}$-eq. GHG emissions for replaced grid electricity are changed by $+17 \mathrm{t} \mathrm{CO}_{2}$-eq in the $210 \mathrm{kWp} \mathrm{PV} \mathrm{scenario} \mathrm{and}-13 \mathrm{t} \mathrm{CO}_{2}$-eq in the $630 \mathrm{kWp}$ PV scenario.

Table 6 summarizes the GHG emissions per MWh consumed electricity in the Suha village grid. It contains all investigated options for replaced and consumed grid electricity. In the $210 \mathrm{kWp}$ PV scenario, specific GHG emissions are increased in "UC2: BESS implementation" between $1 \%$ and $10 \%\left(2-19 \mathrm{~kg} \mathrm{CO}_{2}\right.$-eq/MWh), depending on the investigated option for consumed and replaced grid electricity. On the other hand, in the $630 \mathrm{kWp}$ PV scenario, the UC2 with the battery saves GHG emissions between $24 \%$ and $77 \%$ (46-71 kg $\mathrm{CO}_{2}$-eq/MWh) compared to the UC1 without the battery. 
Table 6. Specific GHG emissions per MWh electricity demand in $\left[\mathrm{kg} \mathrm{CO}_{2}\right.$-eq/MWh] for different UC of the Slovenian pilot site and four options for replaced and consumed grid electricity.

\begin{tabular}{|c|c|c|c|c|c|}
\hline \multicolumn{2}{|c|}{ Power Generation Type } & \multicolumn{2}{|c|}{$210 \mathrm{kWp}$ PV } & \multicolumn{2}{|c|}{$630 \mathrm{kWp}$ PV } \\
\hline \multirow{2}{*}{ Consumed Grid Electricity } & \multirow{2}{*}{$\begin{array}{l}\text { Replaced Grid } \\
\text { Electricity }\end{array}$} & $\begin{array}{c}\text { UC1: PV } \\
\text { Curtailment }\end{array}$ & $\begin{array}{c}\text { UC2: BESS } \\
\text { Implementation }\end{array}$ & $\begin{array}{c}\text { UC1: PV } \\
\text { Curtailment }\end{array}$ & $\begin{array}{c}\text { UC2: BESS } \\
\text { Implementation }\end{array}$ \\
\hline & & \multicolumn{4}{|c|}{ [kg CO${ }_{2}$-eq/MWh] } \\
\hline Slovenian grid mix & Slovenian grid mix & 249 & 268 & 139 & 87 \\
\hline Slovenian grid mix & $\begin{array}{c}\text { Natural gas CC } \\
\text { power plant }\end{array}$ & 223 & 225 & 75 & 17 \\
\hline $\begin{array}{l}\text { Slovenian grid mix + pump } \\
\text { hydro storage }\end{array}$ & $\begin{array}{l}\text { Stored in pump } \\
\text { hydro storage }\end{array}$ & 269 & 280 & 188 & 143 \\
\hline Natural gas CC power plant & $\begin{array}{l}\text { Natural gas CC } \\
\text { power plant }\end{array}$ & 295 & 313 & 139 & 68 \\
\hline
\end{tabular}

The results for the GHG emissions for the electricity supply of the Suha residential grid show that, in the current situation, the battery increases GHG emissions for this pilot site, as PV curtailment is rarely needed. However, if in the future a higher share of PV units is connected to the Suha village residential grid the battery integration could have a positive effect on GHG emissions, depending on the amount of curtailment avoided by the battery.

\subsection{GHG Emissions of a Battery Storage in a Factory in Spain}

Figure 11 depicts the annual GHG emissions for the four investigated use cases for the electricity supply of a Spanish factory. The figure includes the total annual GHG emissions, GHG emissions from PV plant manufacturing, battery manufacturing, electricity consumed from the grid and electricity supplied to the grid. Surplus electricity from the PV generation on site is injected into the grid, which replaces other types of electricity generation, and therefore the GHG emissions linked to this electricity flows are negative. In Figure 11, the Spanish electricity mix was used for consumed and replaced grid electricity.

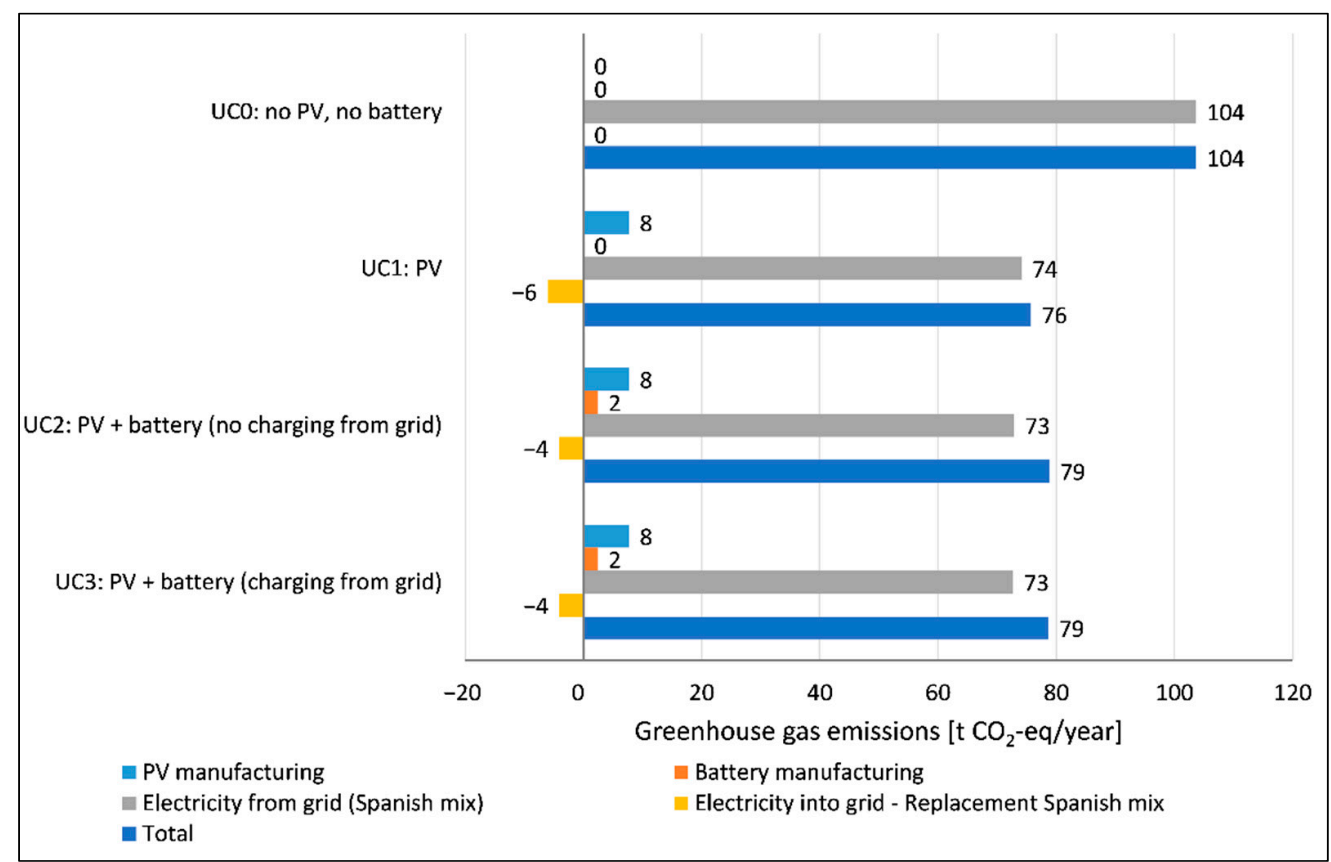

Figure 11. Annual GHG emissions for the Spanish pilot site (Spanish grid mix for consumed and replaced grid electricity). 
UC0 has the highest GHG emissions, where the total electricity demand is covered by the grid. By adding the PV plant in UC1, the annual GHG emissions are reduced from 104 to 76 t CO2-eq. Adding a battery to the system (UC2 and 3) slightly increases the annual GHG emissions to $79 \mathrm{t} \mathrm{CO}_{2}$-eq. The battery leads to a small decrease in GHG emissions for consumed grid electricity. However, it also reduces the replaced GHG emissions from surplus PV injected into the grid and adds GHG emissions from battery manufacturing.

We could not demonstrate a difference in GHG emissions, whether the battery is only charged by PV or also by the grid. UC2 and UC3 are very similar in the amounts of electricity consumed from the grid and electricity injected into the grid (Table 5). However, times of electricity consumption and injection are different and were included in the assessment by using hourly EF for grid electricity. However, the influence of these hourly EFs is too small to be reflected in the results. Overall, the battery changes the energy flows of the system only to a very small degree and therefore the GHG emissions of UC1, UC2 and UC3 are very similar. This is explained in the function of the battery: the battery is used for peak shaving only, and therefore only a small fraction of the total electricity demand of the factory is influenced by the battery.

Like for Suha, in Navarra we see that battery manufacturing contributes minimally $(2.5 \%)$ to the total annual GHG emissions of the factory's electricity supply. However, for this pilot site the use phase of the battery also has a small influence on the GHG emissions as battery operation changes the amount of consumed and injected grid electricity only to a very small degree. Besides roundtrip efficiency and the electricity mix of the system, the size of the battery in relation to the electricity demand of the system it is integrated to and the way of operation of the battery also influence the GHG emissions in the use phase. This result is in agreement with Baumann et al. [8] and Hiremath et al. [7].

Table 7 summarizes the specific GHG emission per MWh electricity demand of the demonstration site for the different options for consumed and replaced grid electricity. The specific values per MWh change, as the investigated options for electricity generation have different GHG emissions. However, the result of the UC comparison is the same for all options: UC0 without PV and battery has the highest specific GHG emissions (214-425 kg $\mathrm{CO}_{2}$-eq/MWh). UC1, with PV electricity, has lower specific GHG emissions (142-293 kg $\mathrm{CO}_{2}$-eq/MWh). Adding the battery to the system increases the specific GHG emission in UC2 and UC3 slightly (152-302 kg CO 2 -eq/MWh).

Table 7. Specific GHG emissions per MWh electricity demand in $\left[\mathrm{kg} \mathrm{CO}_{2}\right.$-eq/MWh] for different UC of the Spanish pilot site and four options for replaced and consumed grid electricity.

\begin{tabular}{|c|c|c|c|c|c|}
\hline \multicolumn{2}{|c|}{ Power Generation Type } & UC0: no PV, No Battery & UC1: PV & $\begin{array}{l}\text { UC2: PV+battery (No } \\
\text { Charging from Grid) }\end{array}$ & $\begin{array}{c}\text { UC3: PV+battery } \\
\text { (Charging from Grid) }\end{array}$ \\
\hline $\begin{array}{c}\text { Consumed Grid } \\
\text { Electricity }\end{array}$ & $\begin{array}{l}\text { Replaced Grid } \\
\text { Electricity }\end{array}$ & \multicolumn{4}{|c|}{$[\mathrm{kg} \mathrm{CO}$-eq/MWh] } \\
\hline Spanish grid mix & Spanish grid mix & 214 & 156 & 162 & 162 \\
\hline Spanish grid mix & $\begin{array}{l}\text { Natural gas CC } \\
\text { power plant }\end{array}$ & 214 & 142 & 153 & 152 \\
\hline $\begin{array}{l}\text { Spanish grid mix }+ \\
\text { pump hydro storage }\end{array}$ & $\begin{array}{l}\text { Stored in pump } \\
\text { hydro storage }\end{array}$ & 214 & 158 & 164 & 164 \\
\hline $\begin{array}{c}\text { Natural gas CC } \\
\text { power plant }\end{array}$ & $\begin{array}{l}\text { Natural gas CC } \\
\text { power plant }\end{array}$ & 425 & 293 & 302 & 301 \\
\hline
\end{tabular}

For this pilot site, the assessment of four use-cases shows that adding the PV unit to the factory had a positive effect on GHG emissions. It reduced the annual GHG emissions between $26 \%$ and $34 \%$ compared to the situation where the grid only covered the electricity demand. Adding a Li-ion battery to the system increased the GHG emissions due to losses in the energy storage process and additional GHG emissions from the manufacturing of the battery. However, the increase in GHG emissions is small (6 to $11 \mathrm{~kg} \mathrm{CO}$-eq/MWh), as only a small fraction of the total electricity demand of the factory is influenced by the battery. 


\section{Conclusions}

In the regional comparison on GHG emissions of battery manufacturing, we identified primary aluminum production, cathode paste production and battery cell production as the driving forces for GHG emissions and regional variation in production GHG emissions due to high electricity demands and the reliance on the national grid. Another important factor is the gravimetric energy density, as a lower value leads to increased material demands for providing $1 \mathrm{kWh}$ of storage capacity and therefore possibly higher GHG emissions. For the base case, we obtained mean values ranging from $77 \mathrm{~kg} \mathrm{CO}$-eq/ $\mathrm{kWh}$ battery capacity for European production of the battery racks in Suha up to $153 \mathrm{~kg} \mathrm{CO}$-eq/ $\mathrm{kWh}$ battery capacity for Chinese production of the battery racks with lower energy density in Navarra. If electricity from photovoltaics fully covers the energy demand of the cell manufacturing process of the European produced battery racks in Suha, the GHG emissions could be lowered to a mean value of $57 \mathrm{~kg} \mathrm{CO}$-eq/ $\mathrm{kWh}$ battery capacity.

GHG emission assessment on the electricity supply of two pilot sites showed that the implementation of batteries may lead to GHG emissions savings, at the Suha pilot site between $24 \%$ and $77 \%$, if their operation enables an increase in renewable energy sources in the electricity system. In the investigated pilot sites, this point was not reached with the current RES penetration rate. Hence, adding the battery always resulted in slightly more emissions (from 1 to $10 \%$ more) than without a battery. The electricity grid was able to transport surplus electricity to other consumers, without facing severe technical problems. The electricity grid had lower losses compared to storage in a battery. However, in a future scenario with a higher amount of PV units, we reached the point where PV curtailment was needed. Here, the battery showed a potential for significant GHG emissions savings.

The LCA assessments on the pilot sites also showed that it is important to implement an energy system view, rather than looking on the effects on the demonstration site only. Including effects from surplus PV electricity in the electricity grid had a significant influence on the total GHG emissions linked to the pilot sites.

Author Contributions: Conceptualization, J.P.-S., C.A. and A.T.; methodology, J.P.-S., C.A., J.Z., A.G., C.N., D.N.B. and G.J.; formal analysis, J.P.-S., C.A., J.Z., C.N. and D.N.B.; writing-original draft preparation, J.P.-S., C.A., D.N.B. and J.Z.; writing-review and editing, J.P.-S., C.A., J.Z., A.G., C.N., D.N.B., G.J. and A.T.; supervision, G.J., A.T. and A.G. funding acquisition, A.G., G.J. and A.T. All authors have read and agreed to the published version of the manuscript.

Funding: The research on the Spanish and Slovenian pilot sites has received funding by the European Union's Horizon 2020 research and innovation programme under grant agreement No 646426, Project STORY-H2020-LCE-2014-3. The review of LCA studies and the development and testing of the "JR Battery LCA Tool" was funded by the Climate and Energy Fund and Austrian Research Promotion Agency (FFG), FFG grant number 865135, and was done in the IEA HEV Task 30 "Assessment of Environmental Effects of Electric Vehicles" in cooperation with the task members.

Institutional Review Board Statement: Not applicable.

Informed Consent Statement: Not applicable.

Data Availability Statement: Not applicable.

Conflicts of Interest: The authors declare no conflict of interest. The funders had no role in the design of the study; in the collection, analyses, or interpretation of data; in the writing of the manuscript, or in the decision to publish the results. 


\section{Appendix A}

Table A1. Emission factors for GHG emissions for different electricity generation technologies $[17,23]$.

\begin{tabular}{|c|c|c|c|c|}
\hline \multirow[b]{2}{*}{ Source } & \multirow[b]{2}{*}{ Technology } & \multicolumn{3}{|c|}{$\begin{array}{l}\text { GHG Emissions } \\
{\left[\text { [kg CO}{ }_{2} \text {-eq/MWh] }\right.}\end{array}$} \\
\hline & & Expert Estimate & Min & Max \\
\hline Nuclear & $\begin{array}{c}\text { Pressurized water reactor } \\
\text { power plant }\end{array}$ & 33 & 8 & 67 \\
\hline Natural gas & Combined cycle power plant & 412 & 400 & 447 \\
\hline Wind & Wind park onshore & 13 & 9 & 28 \\
\hline Fuel & Steam turbine power plant & 799 & 797 & 869 \\
\hline Hydro & Run-of-river power plant & 4 & 1 & 10 \\
\hline Coal & Steam turbine power plant & 960 & 895 & 1087 \\
\hline Brown coal/lignite & Steam turbine power plant & 1064 & 982 & 1092 \\
\hline Waste & Steam turbine power plant & 996 & 448 & 1710 \\
\hline Biogas ${ }^{1}$ & Combined heat and power plant & 252 & 252 & 252 \\
\hline Solid biomass ${ }^{1}$ & Steam turbine power plant & 36 & 36 & 36 \\
\hline Solar-Slovenia ${ }^{2}$ & Photovoltaics & 52 & 42 & 57 \\
\hline Solar-Spain ${ }^{3}$ & Photovoltaics & 45 & 42 & 57 \\
\hline Solar & Concentrated solar power plant & 23 & 19 & 65 \\
\hline
\end{tabular}

${ }^{1}$ no Min/Max value considered, as share in the investigated electricity mix is below $1 \% .{ }^{2}$ for Slovenian solar radiation data. ${ }^{3}$ for Spanish solar radiation data.

Table A2. GHG emissions of the production of the Suha battery for three different production locations (China, US, Europe).

\begin{tabular}{cccc}
\hline & \multicolumn{3}{c}{ GHG Emissions [kg CO $\mathbf{C O}_{\mathbf{2}}$-eq/kWh] } \\
\cline { 2 - 4 } & Lower Range & Expert Estimate & Upper Range \\
\hline Battery China & 109 & 120 & 128 \\
Battery US & 80 & 89 & 97 \\
Battery Europe & 68 & 77 & 84 \\
Additional Equipment & 34 & 44 & 54 \\
Total China & 143 & 164 & 182 \\
Total US & 114 & 133 & 151 \\
Total Europe & 102 & 121 & 138 \\
\hline
\end{tabular}

Table A3. GHG emissions of the production of the Navarra battery for three different production locations (China, US, Europe).

\begin{tabular}{cccc}
\hline & \multicolumn{3}{c}{ GHG Emissions [kg CO $\mathbf{C O}_{\mathbf{2}}$-eq/kWh] } \\
\cline { 2 - 4 } & Lower Range & Expert Estimate & Upper Range \\
\hline Battery China & 142 & 153 & 161 \\
Battery US & 105 & 115 & 122 \\
Battery Europe & 91 & 100 & 107 \\
Additional Equipment & 36 & 46 & 56 \\
Total China & 178 & 199 & 217 \\
Total US & 141 & 161 & 178 \\
Total Europe & 127 & 146 & 163 \\
\hline
\end{tabular}

\section{References}

1. Díaz-González, F.; Sumper, A.; Gomis-Bellmunt, O.; Villafáfila-Robles, R. A Review of Energy Storage Technologies for Wind Power Applications. Renew. Sustain. Energy Rev. 2012, 16, 2154-2171. [CrossRef]

2. Bullich-Massagué, E.; Cifuentes-García, F.-J.; Glenny-Crende, I.; Cheah-Mañé, M.; Aragüés-Peñalba, M.; Díaz-González, F.; Gomis-Bellmunt, O. A Review of Energy Storage Technologies for Large Scale Photovoltaic Power Plants. Appl. Energy 2020, 274, 115213. [CrossRef] 
3. Frate, G.F.; Ferrari, L.; Desideri, U. Energy Storage for Grid-Scale Applications: Technology Review and Economic Feasibility Analysis. Renew. Energy 2021, 163, 1754-1772. [CrossRef]

4. Momoh, J.A. Smart Grid Design for Efficient and Flexible Power Networks Operation and Control. In Proceedings of the 2009 IEEE/PES Power Systems Conference and Exposition, Seattle, WA, USA, 15-18 March 2009; pp. 1-8. [CrossRef]

5. Sbordone, D.A.; Di Pietra, B.; Bocci, E. Energy Analysis of a Real Grid Connected Lithium Battery Energy Storage System. Energy Procedia 2015, 75, 1881-1887. [CrossRef]

6. Pellow, M.A.; Ambrose, H.; Mulvaney, D.; Betita, R.; Shaw, S. Research Gaps in Environmental Life Cycle Assessments of Lithium Ion Batteries for Grid-Scale Stationary Energy Storage Systems: End-of-Life Options and Other Issues. Sustain. Mater. Technol. 2020, 23, e00120. [CrossRef]

7. Hiremath, M.; Derendorf, K.; Vogt, T. Comparative Life Cycle Assessment of Battery Storage Systems for Stationary Applications. Environ. Sci. Technol. 2015, 49, 4825-4833. [CrossRef]

8. Baumann, M.; Peters, J.F.; Weil, M.; Grunwald, A. $\mathrm{CO}_{2}$ Footprint and Life-Cycle Costs of Electrochemical Energy Storage for Stationary Grid Applications. Energy Technol. 2017, 5, 1071-1083. [CrossRef]

9. Ryan, N.A.; Lin, Y.; Mitchell-Ward, N.; Mathieu, J.L.; Johnson, J.X. Use-Phase Drives Lithium-Ion Battery Life Cycle Environmental Impacts When Used for Frequency Regulation. Environ. Sci. Technol. 2018, 52, 10163-10174. [CrossRef]

10. Vandepaer, L.; Cloutier, J.; Amor, B. Environmental Impacts of Lithium Metal Polymer and Lithium-Ion Stationary Batteries. Renew. Sustain. Energy Rev. 2017, 78, 46-60. [CrossRef]

11. Neumann, C.; Pucker-Singer, J.; Türk, A.; Zupančič, J.; Gubina, A. The Role of Storage Systems in Industrial and Residential Environments. Proceedings 2020, 65, 25. [CrossRef]

12. International Organization for Standardization (ISO). ISO 14040:2006(E); International Organization for Standardization: Geneva, Switzerland, 2006.

13. Myhre, G.; Shindell, D.; Bréon, F.-M.; Collins, W.; Fuglestvedt, J.; Huang, J.; Koch, D.; Lamarque, J.-F.; Lee, D.; Mendoza, B.; et al. Anthropogenic and Natural Radiative Forcing. In Climate Change 2013: The Physical Science Basis; Contribution of Working Group I to the Fifth Assessment Report of the Intergovernmental Panel on Climate Change; Cambridge University Press: Cambridge, UK, 2013; pp. 659-740. [CrossRef]

14. IPCC. 2019 Refinement to the 2006 IPCC Guidelines for National Greenhouse Gas Inventories; Calvo Buendia, E., Tanabe, K., Kranjc, A., Jamsranjav, B., Fukuda, M., Ngarize, S., Osako, A., Pyrozhenko, Y., Shermanau, P., Federici, S., Eds.; IPCC: Geneva, Switzerland, 2019.

15. Aichberger, C.; Jungmeier, G. Environmental Life Cycle Impacts of Automotive Batteries Based on a Literature Review. Energies 2020, 13, 6345. [CrossRef]

16. Aichberger, C.; Beermann, M.; Jungmeier, G. LCA of EV Batteries-Materials, Production, Recycling. IEA HEV Task 40 CRM4EV Webinar 2, 10 June 2020, CRM4EV, Webinar Presentation. Available online: https:/ / crm4ev.org/event/task-40-crm4evwebinarsjune-9-10-11/ (accessed on 2 June 2021).

17. Wernet, G.; Bauer, C.; Steubing, B.; Reinhard, J.; Moreno-Ruiz, E.; Weidema, B. The Ecoinvent Database Version 3 (Part I): Overview and Methodology. Int. J. Life Cycle Assess. 2016, 21, 1218-1230. [CrossRef]

18. Argonne National Laboratory GREET Model: The Greenhouse Gases, Regulated Emissions, and Energy Use in Transportation Model. 2019. Available online: https:/ / greet.es.anl.gov/ (accessed on 28 September 2020).

19. IINAS. GEMIS 5.0-Global Emissions Model for Integrated Systems. Available online: http://iinas.org/gemis.html (accessed on 28 September 2020).

20. IEA. International Energy Agency, Data and Statistics, IEA. Available online: https:/ / www.iea.org/data-and-statistics (accessed on 10 November 2020).

21. Hill, N.; Amaral, S.; Morgan-Price, S.; Nokes, T.; Bates, J.; Helms, H.; Fehrenbach, H.; Biemann, K.; Abdalla, N.; Jöhrens, J.; et al. Determining the Environmental Impacts of Conventional and Alternatively Fuelled Vehicles through LCA; European Commission: Brussels, Belgium, 2020.

22. NREL. Life Cycle GHG Emissions from Solar Photovoltaics. Available online: https://www.nrel.gov/docs/fy13osti/56487.pdf (accessed on 6 December 2018).

23. IINAS. GEMIS 4.95-Global Emissions Model for Integrated Systems. Available online: http://iinas.org/gemis.html (accessed on 28 September 2020).

24. MathWorks. MATLAB. 2021. Available online: https:/ /www.mathworks.com/products/matlab.html (accessed on 19 April 2021).

25. SourceForge. OpenDSS. 2018. Available online: https://sourceforge.net/projects/electricdss/ (accessed on 19 April 2021).

26. ENTSO-E. ENTSO-E Transparency Platform. Actual Generation per Production Type. Available online: https://transparency.entsoe. eu/ (accessed on 9 March 2020).

27. Romare, M.; Dahllöf, L. The Life Cycle Energy Consumption and Greenhouse Gas Emissions from Lithium-Ion Batteries; IVL Swedish Environmental Research Institute: Stockholm, Sweden, 2017.

28. The International Aluminium Institute. World Aluminium-Primary Aluminium Smelting Power Consumption. Available online: http:/ / www.world-aluminium.org/statistics/primary-aluminium-smelting-power-consumption/\#data (accessed on 28 September 2020).

29. Kelly, J.C.; Dai, Q.; Wang, M. Globally Regional Life Cycle Analysis of Automotive Lithium-Ion Nickel Manganese Cobalt Batteries. Mitig. Adapt Strateg. Glob. Chang. 2020, 25, 371-396. [CrossRef] 
30. Dai, Q.; Kelly, J.C.; Gaines, L.; Wang, M. Life Cycle Analysis of Lithium-Ion Batteries for Automotive Applications. Batteries 2019, 5, 48. [CrossRef]

31. Ellingsen, L.A.-W.; Majeau-Bettez, G.; Singh, B.; Srivastava, A.K.; Valøen, L.O.; Strømman, A.H. Life Cycle Assessment of a Lithium-Ion Battery Vehicle Pack: LCA of a Li-Ion Battery Vehicle Pack. J. Ind. Ecol. 2014, 18, 113-124. [CrossRef]

32. Davidsson Kurland, S. Energy Use for GWh-Scale Lithium-Ion Battery Production. Environ. Res. Commun. 2019, 2, 012001. [CrossRef]

33. Emilsson, E.; Dahllöf, L. Lithium-Ion Vehicle Battery Production Status 2019 on Energy Use, CO2 Emissions, Use of Metals, Products Environmental Footprint, and Recycling; IVL Swedish Environmental Research Institute: Stockholm, Sweden, 2019. 